\title{
Public Budget Ratcheting: \\ Do Malaysia Federal Government Agencies Adjust Their Budgets Based on Expenditure Variances?
}

\author{
Daw Tin Hla, Chang Sze Ping, Abu Hassan Md. Isa, \\ Michael Tinggi, Shaharudin Japar and Sophee S. Balia \\ Department of Accounting and Finance, Faculty of Economics and Business \\ UNIMAS Malaysia
}

\begin{abstract}
Public budget is an important role in achieving a country's economic and social development goals. It essentially requires that an entire government budget be managed effectively and efficiently to ensure attainment of those goals as well as well-being of the citizens. Therefore, it is necessary to examine government spending behaviour and the process of budget preparation. This study looks into the relationship between changes in current budget and expenditure variances, in particular, operating expenditure of the Malaysia federal government. The influence of expenditure variances (overspending/ under spending) on current budget changes is examined to determine if prior year expenditure variances cause non-symmetry changes in current budget so as to identify the presence of budget ratcheting. Dynamic Panel Regression Analysis is used to examine the data from forty four government agencies/programs, covering the period from 2010 until 2014. The findings reveal that there is a significant positive association between changes in current budget with prior year overspending by agency/program. However, the relationship between changes in current budget with prior year underspending by agency/program is not significant. The contribution of the research highlights that the presence of budget ratcheting among the federal government agencies/programs of public organisations needs to be indicated to enhance budget administration regarding ratcheting.
\end{abstract}

Key words: Budget Ratcheting, Expenditure Variances, Auto Correlation and Panel Regression JEL Classification Code: M41 M48 and C33

The authors acknowledge the financial support rendered by Universiti Malaysia Sarawak (UNIMAS) through the fundamental Research Grant No.FRGS/SS01(1)/1086/2013(32).

\section{INTRODUCTION}

Government budget is an important tool for every country to attain its economic and social development goals. It is far more important than those in private sector because of its pivotal role in ensuring equitable distribution of wealth to all citizens. There are two major components in government budget, namely revenues and expenditures. Budgeting in public sector differs from private sector. While private sector focuses on budgeting earnings, public sector budgets expenditures (Lee \& Plummer, 2007). Hence, analysing government spending behaviour is vital to ensure allocation of resources is done in a responsive, efficient and effective manner.

Malaysia government has implemented Outcome Based Budgeting starting year 2012 to improve public budget management following increasing fiscal challenges. However, it is of common perception that government expenditures are associated with non-optimal spending. 
Numerous weaknesses with regards to public finance have also been addressed by National Audit Department through the annual Auditor General Report. The most frequent issues raised are related to inefficiency of government officials in managing public funds and unconscionable wastage of public funds that involves millions of ringgit every year. This wastage and mismanagement of government resources remain a major impediment to government efforts to developing sustainable fiscal policies and economic growth. Notwithstanding government's continuous efforts to improve the structure of budget allocation and expenditure to be more efficient and effective, it seems as though there is never lack of issue about poor management of government funds.

In Malaysia federal government context, it draws the question of how budget administrators in public sector budget their agency expenditures during the early part of budgeting process. That is, what basis they use in determining the amount of budget needed by their agency to implement planned programs? The most common approach would probably be to derive budget figures based on prior year expenditure performance, meaning current budget is adjusted according to past spending records. However, government agencies may exhibit dissimilar degree of budget adjustments in response to past expenditure, wherein this differential response is termed ratcheting.

Hence, this study examines ratcheting of government spending, which is to what extent the Malaysia federal government agencies incorporate prior year spending variances into their budgeted expenditures. This study conjectures that government agencies respond more to overspending than underspending. That is, budget increment which corresponds to prior year overspending (actual exceeds budget) shows larger magnitude of budget changes relative to budget decrement which corresponds to prior year underspending of the same amount. In other words, spending variances do not project commensurate changes in the agency's budget. In this study, it is hypothesized that the operating budget of Malaysia federal government departments ratchets. This topic is of interest because ratcheting of budget is not reckoned a desirable behaviour in public sector as it is associated with inefficiency. Nevertheless, it is also possible that government officials are incapable to reduce expenditures due to other explanatory reasons such as "cost stickiness" or they truly of the opinion that budget increase will contribute to the welfare of the people.

Managing public funds is a great responsibility that government officials must shoulder well to ensure resources are put to effective use which benefits the society. If there is an increase in government's budgeted expenditure, the public would expect improvement in quantity and/or quality of the goods and services rendered to the public at the same time. Ratcheting of budget in public sector is not desirable because the agency who applies for annual budget may tend to not reveal full details related to its programs/activities in order to gain from asymmetric information. Moreover, using prior year overspending to justify for additional budget for programs or activities which are going to be implemented in subsequent period is perhaps the easiest way since data is already available. Despite the fact that justification of budget expansion may be supported by adequate quantitative data from respective agency, one cannot rule out the possibility that the basis for setting budgeted expenditure is actually not reflecting the real capacity of the agency.

Therefore, this study aims to identify the presence of budget ratcheting in public sector, specifically Malaysia federal government's operating budget. For this purpose, the relationship between agency/program's prior year expenditure variances and current budget change is examined. 


\section{RESEARCH DESIGN}

While there are vast studies related to distributive impacts and macroeconomic effects of public spending, less is known about the budgetary process at micro level, which is the agency's involvement in preparing and deriving budget figures. In particular, how ratchet principle is associated to determination of the budget amount. Although prior research shows that ratcheting is beneficial to firm (Leone \& Rock, 2002), ratchet effect is linked to inefficiency in public sector (Roland, 2013). With rising expectations to deliver a people-based government budget, as well as greater fiscal challenges and heightened budget constraints, it is even more pressing to examine budget ratcheting in the government environment so that resources are utilized optimally.

Operating expenditure is of concern in this context because it constitutes a big portion of total federal budget despite the fact that development expenditure is said to have larger economic multiplier effects. Nevertheless, expenditure components such as operation and maintenance may have higher rates of return than capital expenditure (Devarajan, Swaroop, \& Zou, 1996), indicating the equally important role of operating expenditure in public spending in Malaysia.

At the time of writing this paper, there has been no similar study undertaken in the public sector in Malaysia. Therefore, the purpose of this study is to examine the presence of budget ratcheting, notably operating budget (expenditure) of the federal government in Malaysia. It is intended that the findings of this study will provide meaningful guidelines to officials at treasury department so that they are aware of the degree to which budget administrators at agency adjust their current year budget based upon prior year expenditure variances. It is also hoped that this paper will aid in ensuring government accountability and improving service delivery to the public through efficient usage of resources.

In order to examine if operating expenditure of Malaysia federal government agency ratchets, the following question is used as guidelines to obtain information needed so that the objective of the study can be fulfilled: What kind of relationship that exists between changes in federal government agencies/programs' current budget and prior year expenditure variances?

The general objective of this study is to analyse the relationship between prior year expenditure variances and current budget change of operating expenditure of Malaysia federal government. This study attempts to determine whether or not prior year expenditure variances cause nonsymmetry changes in current budget with the ultimate aim to explore the presence of ratcheting of budget, specifically operating expenditure budget of Malaysia federal government.

The specific objectives of this study are:

i) To determine the relationship between prior year overspending and changes in current operating expenditure budget of Malaysia federal government agencies/programs.

ii) To investigate the relationship between prior year underspending and changes in current operating expenditure budget of Malaysia federal government agencies/programs.

\section{$2.1 \quad$ Conceptual Framework}

The proposed conceptual framework for budget ratcheting in public sector is depicted in Figure 1. Conceptual framework is important to set the frame for analysing the presumed relationship between the independent and dependent variables to be studied. A well-developed framework 
will facilitate researcher to be aware and understand the situation under scrutiny and make meaning of subsequent findings (Smyth, 2004).

The idea of the conceptual framework in this study is based on Lee and Plummer's (2007) model. The study tries to explain the relationship between current budget change (dependent variable) and expenditure variances (independent variable) in which the expenditure variances refer to prior year overspending (actual exceed budget) and prior year underspending (budget exceed actual). As shown in the conceptual framework, the expenditure variances and current budget change are predicted to relate to one another, whereby expenditure variances are expected to exert influence on current budget. Although the independent variables are homogeneous in nature (both are associated with government spending), the variable will be examined separately in order to determine the extent of how each variable affects the changes in budgeted operating expenditure of the federal government agency/program.

\section{Figure 1. Conceptual Framework}

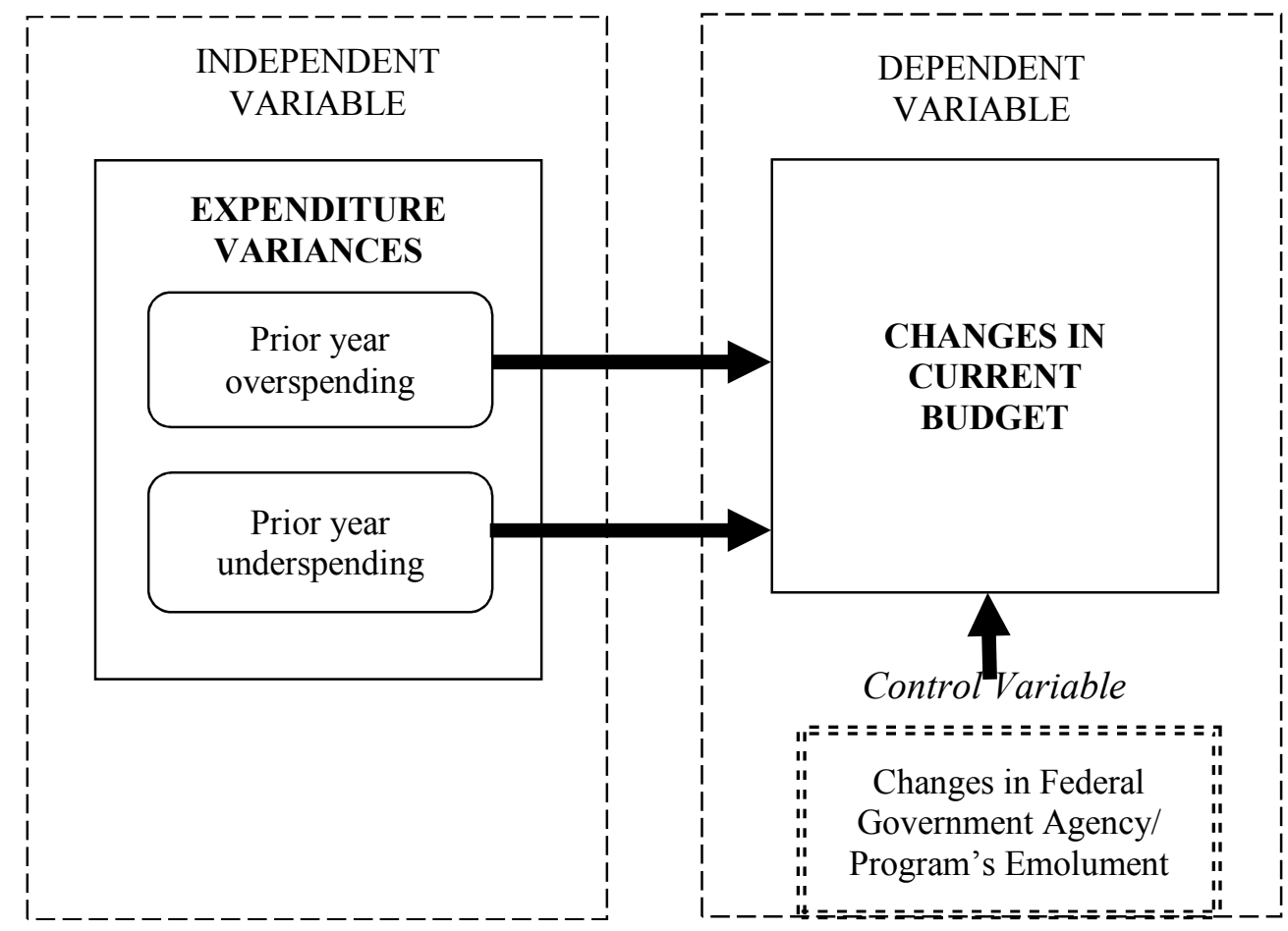

Source: Adapted from Lee and Plummer's model (2007).

\subsection{Research Hypotheses}

The following three hypotheses are postulated to test whether prior year favourable or unfavourable variances are taken into consideration in preparing current year budget or not. The first hypothesis is that overspending of operating expenditure in government agencies, which are taken into consideration in current budget and it is to be operationalized as follow: 
H1: There is significant positive relationship between Malaysia federal government agency/program's prior year operating expenditure overspending and current budget change.

The second hypothesis is to test if the prior year underspending of operating expenditure is considered to do adjustment in preparing current year budget and it is hypothesised to be operationalised as stated:

H2: There is significant negative relationship between Malaysia federal government agency/program's prior year operating expenditure underspending and current budget change.

\subsection{Significance of the Study}

This study has two major contributions. First, it contributes to the general understanding of budget ratcheting in the public sector in Malaysia. This will give researchers an overview of ratcheting of budget in government setting and perhaps facilitate them in conducting in-depth empirical test in selected area in the future.

Second, as prior studies were conducted in the private sector, it is hoped that the findings of this study will be beneficial to the policy makers and relevant treasury divisions who are responsible for overseeing, coordinating, checking, screening and/or endorsing the yearly estimated operating expenditure of federal government departments. This will assist them in making appropriate considerations and deriving optimal decisions with regards to budget application submitted by department/agency before the budget proposal is presented for approval by the Parliament.

\section{LITERATURE REVIEW}

Ratchet is widely discussed in various literatures in different fields covering economics, sociology, science, engineering and others. It has two distinct meanings. One describes the mechanical device for technical application, and the other is used in planning and regulatory contexts. In terms of non-technical definition, ratchet is defined as a situation or process that is perceived to be changing in a series of irreversible steps ("Ratchet", 2015).

The common topics which are of interest by researchers are ratchet effect and ratchet principle. Ratchet effect and ratchet principle are used interchangeably, although both signify different states of ratcheting. From the perspective of sociology, ratchet effect refer to the "tendency for central controllers to base next year's targets on last year's performance, meaning that managers who expect still to be in place in the next target period have a perverse incentive not to exceed targets even if they could easily do" (Bevan \& Hood, 2006, p.521). In another dimension, Milgrom and Roberts (1992) state that "The tendency for performance standards to increase after a period of good performance is called the ratchet effect." (as cited in Indjejikian \& Nandap, 2003, p. 438). Ratchet principle is described as the tendency to use "current performance as a partial basis for setting future targets" (Weitzman, 1980, p.302). It is noticeably that there exists difference between the aforementioned terms. Roland and Szafarz (1990) also make this point that ratchet should not be confused with ratchet effect. They argue that ratchet effect need not necessarily take place despite the possibility that planning with ratchet prevail. However, it is not a major concern in this study as the focus is to determine whether ratcheting of budget occurs in public sector. 


\subsection{Spending Behaviour of Government}

There is one theory related to government spending behaviour that can be applied in this study to explain the occurrence of expenditure ratcheting in public sector. It is called budget-maximizing model which is inaugurated by William Niskanen in 1971. According to this theory, bureaucrats are rational and pursue budget-maximizing strategy because of self-interest reason, which is to gain greater access to salary, perquisites, reputation, power and patronage. Not only they make the attempt but they also succeed in expanding their budgets due to two reasons: informational advantages about the programs they run and the lump-sum budget appropriations allocate to them for their services. The bureaucrats in this context can be referred to government agencies officials that seek to maximize their budgets. Larger budget implies the relatively importance of their agency in delivering services to the public. Therefore, the grounds become more solid to keep the existence of their agencies which also implicit that their jobs will be secured.

Niskanen's theory of government budgeting has received much comments and criticism from scholars (Migué \& Bélanger, 1974; Conybeare, 1984; Casas-Pardo \& Puchades-Navarro, 2001). They question about the assumption of the model and claim that Niskanen's proposition holds only in certain context. Sigelman (1986) notes that career-minded bureaucrats may have the view that rather than contemplating on how to maximize budget, achieving designated program objectives with minimal budget/spending is seen as more competent and that this would help in their career advancement.

Nonetheless, federal government is probably the most favourable setting to test Niskanen's model (McGuire, 1981) as decisions about the provision of public goods and services are mostly made by central agency or federal government. Besides, measuring the performance of government departments or civil servants is indeed a difficult task due to lack of yardstick competition (Tirole, 1994), suggesting federal government officials are likely to engage in budget ratcheting. Hence Niskanen's budget maximizing theory is considered relevant to examine ratcheting of federal government expenditures in Malaysia.

\subsection{Literature Review on Budget}

Budget is one of the most significant policy documents for organizations where it serves as a tool to make sure the organization's actual activities and performances are least deviated from what is originally planned. Budgeting has always been a central plank of most organization's control mechanisms in which it forms part of the management control process. Robert Anthony (1965) describes management control as "managers assure that resources are obtained and used efficiently and effectively in the accomplishment of the organization's objectives" (as cited in Kaplan, 2010, p. 7). Notwithstanding criticism that budgeting prevents inefficient use of organizational resources as well as encourages myopic decision making and induces budget games and dysfunctional behaviour (Schmidt, 1992; Ekholm \& Wallin 2000; Marcino, 2000; Jensen, 2001), it remains a key role in helping the management to attain organizational goals as budget compels management to think about the future, which is perhaps the most vital element in the budgetary planning and control system. Moreover, the frequent association between budgeting and accounting (Wooldridge, Garvin, \& Miller, 2001; Robinson, 2002; Van der Hoek, 2005; Pollack, 2014), and the fact that accounting is the "language of business" have established the commonalities in almost all organizations. Such commonalities and the necessity of both budgeting and accounting in the management of government at internal and external level as postulated by Trebby and Daniker (1986) suggest that management control through budget is still extensively required, more so in the public sector which consists of complex open system of agencies with various tasks. 
Lassègue (1988) asserts that "the virtue of budgeting is that it provides an encompassing framework by means in which all aspects of an organizations' activity are encapsulated into a single set of financial statements" (as cited in Stonkute \& Žukaskas, 2003, p. 275). This indicates budgeting activity is comprehensive in nature and that it is able to facilitate effective control. As a result, unnecessary public spending can be reduced and sufficient financial resources can be allocated to other productive public projects. Figure 3 illustrates how budgeting can be placed in the overall management control system and its core role in the management's planning and control function using a control model (organizational control). For the planning phase, budgeting sets specific financial targets to be achieved by the organizations. At the controlling phase, budgetary control compares the actual performance with what has been planned to identify any deviations as well as to seek explanation for the deviations. This will promote efficient use of resources and provide support for other critical government functions.

\subsection{Expenditure Variance and Its Usefulness}

An expenditure variance is the difference between the budgeted or baseline amount of expense, and the actual amount. A favorable expenditure variance refers to desirable difference between budgeted and actual amounts, in other words, positive variances or gains for the organization. In contrary, unfavorable or adverse budget variance means undesirable difference between budgeted and actual values, that is negative variance or losses. Some expenditure variances are controllable while others are not. Controllable variances arise due to factors that are controlled, to a significant extent, by individual or group associated with the organization (Broyles, Khaliq, $\&$ Mattachione, 2009). On the other hand, uncontrollable variances are those which are beyond their control. As Penner (2004) stresses, it is critical that administrators understand the distinction between controllable and uncontrollable variance so that the budget strategy formulated allows sustainability of organization. She advocates all levels of management should work together to investigate sources of variance and focus their attention on those specific variances that can be controlled. This seems logical and sensible as these variances are easier to identify and can be cautioned against in the future.

Variance analysis is useful in evaluating operational performance of an organization because it provides benchmark against which to compare the actual performance. It is a tool often adopted by many profit and non-profit organizations for performance evaluation (for example, measuring production efficiency and effectiveness) and reporting purpose. Several studies that provide evidence for this include Robbins and Taylor (2013), Yap, Lee, Jamaliah Said and Yap (2013), Angelakis, Theriou and Floropoulos (2010), Phadoongsitthi (2003), Joshi (2001), Kloot \& Martin (2001). Their studies show that traditional management accounting such as variance analysis is highly adopted by most organizations, despite many new developments that come under the banner of strategic management accounting (Otley \& Fakiolas, 2000). One point highlighted by $\mathrm{Ho}$ and $\mathrm{Ya} \mathrm{Ni}(2005)$ is that the reported percentage of spending variance in a program budget does not reflect the performance of public service delivery, but rather it serves as a measurement of the budgetary control's intermediate outcomes. Nevertheless, the variance information is an important intermediary step to the end-outcomes of budgetary administration, which include making sure there is sufficient public fund for delivering all the planned programs. Poorly executed variance analysis causes errors, fraud and operational anomalies to go unreported, uncorrected and unexplained. Hence, organization should properly conduct variance analysis as the figures derived from the analysis can be invaluable to the operational aspects of the organization. 
Information from the analysis of variance facilitates management's efforts to improve control over budget system. An effective budget system requires the disciplined totals to be under control and that is the first purpose of the system (Allen \& Tommasi, 2001). One form of controls that managers implement to keep their organizations reliably on track is through performance evaluation reviews (Merchant \& Otley, 2006) in which budget variance analysis falls under. By evaluating the implications of variance, appropriate actions can then be identified to rectify the budget discrepancies. This, in the end, will support effective monitoring and control of expenditures. Regardless of the different accounting practices or objectives between private and public sectors, both, as postulated by Anthony (1980), must "maintain their capital through operations if they are to continue as sound organizations" (p. 392). For that matter, variance analysis serves as an early warning for informing managers of the need for expenditure control before allowing the expenses spiral out of control. It is even more essential to control expenditure in public sector so as to bring about the necessary stability for economic growth and development.

Webb (2002) argues that the existence of policy of investigating budget variance in an organization will exert accountability pressure on managers which in turn lessen budgetary slack. Accountability is the core of public budget governance. Because it conveys an image of transparency and trustworthiness, its role as the foreground of political discourse and policy documents has increasingly become critical (Bovens, 2007). Perrin (2015) concurs this proposition, stating "accountability can be viewed as an end in itself, with the objective of providing for greater confidence or assurance in what government is doing and how." (p. 185). A major purpose of accountability is the legitimization of the exercise of authority, including the most appropriate use of public resources. Therefore, having accountability in the budget process is vital to help ensure public resources are spent in a transparent and efficient way that lead to improved budgetary and development outcomes.

Based on Kidwell's (1999) study on factors that impact government auditor's reporting decisions, unfavorable variance from budgeted expenditures may be used as a materiality guideline for the auditors. The larger the spending variance reported in the municipal's financial statements, the higher the levels of non-compliance reporting option will be used by auditor. It is not surprised to see public auditors adopt such practice since large budget variance usually indicates over-budgeting and inefficiency. Besides, concerned citizens and conscientious legislators will undoubtedly demand stricter adherence to budget targets from government in order to curb government overspending in the hope of reducing current deficit. Thus, greater attention and more stern measures are undertaken by auditors when they encounter significant budget deviations from public organizations.

Organization performs variance analysis to identify and seek explanations of cause of variance so that a more accurate budget can be achieved in the future. In most cases, organizations make some necessary budget adjustments to avoid similar discrepancies in the future. This is supported by Vasarhelyi and Mock (1977) who suggested that explicit variance information leads to improved budget accuracy. Emmanuel et al. (1990) posits that accounting activities provide information that helps make sense of complexity differentiation and uncertainty (as cited in Cassar \& Gibson, 2008) which in turn enhances manager's capacity to make more accurate forecast. Cassar and Gibson (2008) claim firm that compares actual outcomes against planned outcomes through variance report will be in a better position to adjust priors. It is notable that accurate budget is important because it reflects true scenario and 
provides realistic picture to the management which helps in strengthening the organization's planning and control activities.

In another study, Marino and Matsusaka (2005) find that when a project demonstrate large upside (or variance), the principal is more inclined to approval process. This suggests that variance analysis data is able to assist managers to make informed decisions since the occurrence of budget deviations is not something that can be taken lightly. Meanwhile, Marginson, Ogden and Frow (2006) have put forward a suggestion related to the choice of whether or not to ignore budget variance when it arises. Instead of analysing budget variance in isolation at the level of individual responsibility centre, they present another approach: "aggregated variance analysis", which is done in relation to company strategy. Their study shows that aggregated variance analysis greatly enhance managers' capacity to manage flexibly and responsively to events and developments as they occurred. Further review of adopting such approach in a government setting is needed since the nature of public sector is different from private. Nonetheless, continuous improvement of public sector efficiency and quality of public service remains government's goal and therefore, any idea for betterment of current practice is always welcomed.

\subsection{Budget and Ratcheting in Public Sector}

There are several studies pertaining to ratcheting in public sector. Higgs (1987) propounds ratchet theory of government growth in his book, Crisis and Leviathan, in which he explains the temporary government programs that were created to deal with major crisis have become permanent and resulted in historical government growth. This is further argued by Bellante and Porter (1998) who state government growth is attributed by the ratchet effect as consequence of asymmetries in the response of government employment to the business cycle. They find that government exhibited more rapid relative growth as compared to private sector during economic downturn. The asymmetric behavior is also consistent with that reported in Hercowitz and Strawczynski's (2004) study. Their study shows that asymmetric fiscal behavior over business cycle leads to upward cyclical ratcheting in government spending which partially explains the prolonged increase in the spending/GDP ratio in OECD countries. Cyclical ratcheting is particularly observed in the transfer and subsidies component as compared to government consumption and capital expenditure.

As for ratcheting of budget, the first empirical study in a government setting is conducted by Lee and Plummer (2007). They examine the budget of 1,034 independent school districts in Texas over the period 1995 through 2002, and find the presence of ratchet in operating expenditures and the subcategories of instructional expenditures (salaries and benefits for teachers, teachers' aides, cost of instructional supplies and materials) and non-instructional expenditures (cost of school district and campus administration, and guidance, counselling, and social work services). This result is consistent with their prediction that government budgets ratchet. Based on the findings, ratcheting is very evident in the non-instructional expenditures. In addition, when controls on government spending are weakly practiced, meaning the schools operate in a district that is less competitive and do not have strong voter influence, budget ratcheting is found to be more pronounced.

While ratcheting of government budget has some appeal, limited attention has been devoted to this field as studies are mostly conducted for private entities. For example, Leone and Rock (2002) find ratcheting of budget in multinational corporations and they argued that it 
would not remain unchanged through time as assumed in the earnings-management research. Budget is said to be dynamic and endogenously oriented in the business environment. Study shows evidence of asymmetric budget ratcheting by audit firm supervisors (Ettredge, Bedard, \& Johnstone, 2007). In another setting, favourable performance variances of target setting are associated with the decrease in magnitude of ratcheting and vice versa (Aranda, Arellano, \& Davila, 2014). This is because managers whom have self-interest may hold back their efforts in the current period in order to avoid higher targets in the future (Indjejikian, Matějka, \& Schloetzer, 2014).

A country's economic performance can be improved if it increases public spending, especially middle-income countries that are rapidly growing (Yeoh \& Stansel, 2013). This is relevant in Malaysia's case as it is gearing towards high-income nation status by 2020. Public expenditure is commonly characterized into 'productive' and 'unproductive'. According to economic theory, roads, water supply systems, sewers, education and health are posited as productive public capital, but this does not make other public expenditures such as administrative and operating costs less paramount. Nevertheless, it is vital to identify the strategic mix between productive and unproductive expenditure in order to better develop the economy of a country (Devarajan, Swaroop \& Zou, 1996). Malaysia federal government budget is largely made up of operating expenditures which at certain point are less beneficial to country's progress in comparison to development expenditure which helps in fostering economic development. It is therefore crucial to examine the presence of budget ratcheting which is said to be associated with inefficiency, specifically ratcheting of operating expenditures.

Nasaruddin and Zulkifly (1988) carry out a study on Malaysia's government budget by examining the historical pattern of public expenditure according to functional activities and its distribution impacts. They find that expenditure amount has been consistently higher in the last quarter of the fiscal year as compared to earlier quarters, which indicates the respective departments tend to use up the allocated budget to avoid any unspent budget to be surrendered back to Treasury before year ends. Study also shows some government officers at state level operating department used qualitative approach, namely experience and game-playing in forecasting expenditure for the department at state level (Doh, 1991). This may result in some spending becoming unnecessary or inefficient as a consequence of improper planning and careful consideration as time ran out, as well as unavailability of systematic analysis of expenditure.

Public employment differs from that of private employment. One pronounced difference is that public employment contains politically influenced element whereby the system (employer) provides jobs in exchange for political support from the employees (Robinson \& Verdier, 2002). In this case, it is harder to lay off public sector employees. Additionally, government officials are not absolutely tied to performance-linked incentive program such as in private sector. These scenarios, coupled with asymmetric information exists in government environment, allow agencies to expand their budgets with less restriction. If budget increase does not correspond to an equivalent performance improvement in public service delivery, and the increase is not socially desirable, it is likely that the public fund is not prudently managed.

Yet, the possibility remains that government officials' self-interest behavior may not fully contribute to budget ratcheting in public sector. One of the issues that government agencies may face is probably related to "cost stickiness". From the accounting perspective, costs are either in the form of fixed or variable in direct proportion to the quantity of output. However, not 
all costs demonstrate such mechanistic relation between activity and costs behavior. There are costs that are termed "sticky"; meaning the increase in costs associated with increase in volume is greater than the decrease in cost associated with the same amount of decrease in volume (Anderson, Banker, \& Janakiraman, 2003). If the function in an organization represents the core competency of that organization, costs associate with the function are likely to exhibit greater stickiness (Balakrishnan \& Gruca, 2008). This is also the same case in a government setting. Program or activity implemented by the agencies can be sticky if the non-existence of that particular program or activity leads to undesirable intense impact on the public benefits. As a result, government officials are unable to reduce expenditures related to the program or activity.

Ratcheting of federal government budget is deemed a markedly important topic for discussion because of its huge implications for the health of the economy. Besides, all federal government departments/agencies in Malaysia are subjected to the same budget policy which suggests the setting of this study will be identical for examination purpose and the proposed model will be under the same control mechanism. It allows the research situation to be administered in a homogeneous manner so as to examine the relationship between independent and dependent variables. Operating expenditures are selected for analysis instead of development expenditures because operating expenditures are more consistent in nature as they are on-going costs allocated for normal operation of the departments/agencies as compared to development expenditures that are project-based. Moreover, operating expenditures constitute a large portion of the total federal government budget allocation, which implies that sizeable findings may be established through this study.

\section{DEVELOPING RESEARCH MODEL}

Based on the basis of ratchet principle which stated that the formation of next period's goal is partly dependent on current period performance, Weitzman (1980) postulated a research model as follows:

$$
q_{t} \quad q_{t-1}=\delta_{t}+\lambda_{t}\left(y_{t-1} \quad q_{t-1}\right)
$$

The variable $y$ symbolizes an entity's performance while the performance target in period $t$ is denoted as $q_{t}$. The amount of which the target would be changed in period $t$ if last period's target was completely achieved is represented by the independent increment $\delta_{t}$. The adjustment coefficient $\lambda_{t}$ serves as notch that pushes up current period's target in which the notch derives from the surpass of last period's performance over last period's target. Additional notches would imply greater target for current period.

To apply this model in government budget setting, expenditures are used as performance indicator. Government agency is said to be efficient when lower expenditures are incurred for the same level of public services. For that matter, government's budgeted expenditures in period $t$ are represented by $B_{t}$, and actual expenditures are represented by $A_{t}$. The model is demonstrated below:

$$
B_{t} \quad B_{t-1}=\delta+\lambda\left(\begin{array}{ll}
A_{t-1} & \left.B_{t-1}\right)
\end{array}\right.
$$

Equation (2) suggests that current year's budgeted expenditures are partly dependent upon independent increment $\delta$, and last year's budget variance through the adjustment coefficient $\lambda$. In this context, Weitzman (1980) conjectures that conditioned to constant public services, public managers (planners) are rewarded if they did not overspend $\left(A_{t}<B_{t}\right)$. Such 
incentives provision will prompt them to reduce actual expenditures. Weitzman also predicts that public managers will compare the benefits (rewards) from better current performance $\left(A_{t-1}<\right.$ $\left.B_{t-1}\right)$ with the costs derived from such performance in future periods. In the situation where better current performance is attained, $B_{1}$ will be lower in future periods because of the adjustment coefficient $\lambda$. This will make it harder for public managers to gain future rewards.

Nonetheless, this circumstance may not be suitable to be applied in the government environment. As pointed out by Lee and Plummer (2007), government officials are neither financially rewarded nor penalized if they decrease or increase public expenditures. Furthermore, they are not confronted with extremely tight spending restrictions comparing to private sector. Hence, it is predicted that an asymmetric budget-ratcheting pattern exists in public sector. To be precise, the government administrators will exhibit greater response to overspending $\left(A_{t-1}>B_{t-1}\right)$ than underspending by having more adjustment done to their agency's budgets. Lee and Plummer (2007) modify the Equation in (2) to allow for differential adjustments depending on the sign of the variance. This is also consistent with prior studies that examine budget ratcheting as an asymmetric response to budget variances of different signs (Holthausen, Larcker, \& Sloan, 1995; Leone \& Rock, 2002). The modified model is illustrated as below:

$$
B_{t} \quad B_{t-1}=\delta+\lambda^{+}\left(A_{t-1} \quad B_{t-1}\right)+\lambda^{-} U_{t}^{*}\left(A_{t-1} \quad B_{t-1}\right)
$$

The variable $U_{t}$ equals 1 when budgeted expenditures exceed actual expenditures, and 0 otherwise. The adjustment coefficient for overspending $\left(A_{t-1}>B_{t-1}\right)$ is denoted as $\lambda^{+}$, and $\lambda^{-}$ represents the differential coefficient for underspending $\left(A_{t-1}<B_{t-1}\right)$. When the two coefficients are summed up $\left(\lambda^{+}+\lambda^{-}\right)$, it is the adjustment coefficient of underspending. $\lambda^{-}$will be negative when government administrators adjust their budgets more in response to overspending than underspending. In this case, the $\lambda^{-}$is referred to as ratcheting coefficient. Lee and Plummer (2007) argued that the asymmetric ratcheting behavior portrayed by government administrators' is consistent with Weitzman's (1980) model in which future cost of better current performance increases as $\lambda$ increases.

The model adopted in this paper is based on the work of Lee and Plummer (2007) in which they model the change in the Texas school district's budgeted expenditure as a function of the prior year's budget variance and control variables that are likely to affect budget growth. As their scope of study is oriented towards budgeting in the school environment at local government, hence they include control variables such as school district's weighted average daily attendance, number of full-time personnel, school district's average salary, school district's taxable property values, district's beginning fund balance, district's revenues from states and federal funds, and district's actual and budgeted revenues.

However, most of these variables are excluded in this study except budgeted and actual expenditures and average change in salary. In comparison to Lee and Plummer's area of study which targeted at education sector, this study is more general in nature as the aim is to explore the presence of budget ratcheting in public sector so that an initial overview of such budgeting response can first be distinctly known. Thus, variables such as school district's weighted-average daily attendance and school district's number of full-time personnel are not suitable in this context. In addition, the budget environment that the Malaysia federal government agencies are in is different from the budgeting practice in the United States. Therefore, the remaining variables which are school district's taxable property values, district's beginning fund balance, 
district revenues from state and federal funds, and district's actual and budgeted revenues are also excluded from this study.

\subsection{The Research Model}

Due to aforementioned budget setting, Lee and Plummer's model is modified to suit the objective of this study. The modified model is illustrated as follows:

$$
\begin{aligned}
& \left(B_{i t} \quad B_{i t-1}\right) / B_{i t-1}=\alpha_{0} / B_{i t-1}+\alpha_{1} U / B_{i t-1}+\lambda^{+}\left(A_{i t-1} \quad B_{i t-1}\right) / B_{i t-1} \\
& +\lambda^{-} U\left(\begin{array}{ll}
A_{i t-1} & B_{i t-1}
\end{array}\right) / B_{i t-1}+\alpha_{2}\left(E_{i t} \quad E_{i t-1}\right) / E_{i t-1} \\
& +\varepsilon
\end{aligned}
$$

Where:

$B_{t}$ and $B_{t-1} \quad=$ an agency/program's budgeted operating expenditure for year $t$ and year $t-1$;

$A_{t-1} \quad=$ an agency/program's actual operating expenditure for year $t-1$

$U \quad=1$ if $\left(\begin{array}{ll}A_{t-1} & B_{t-1}\end{array}\right)$ is negative, and 0 otherwise

$E_{t}$ and $E_{t-1} \quad=$ an agency/program's budgeted emolument expenditure for year $t$ and year $t-1$.

As explained in Lee and Plummer's model (to include year here), the financial variables are deflated by estimated operating expenditure for year $t-1\left(B_{t-1}\right)$ so that the scale effects can be controlled. Moreover, it is easier to explain the results of coefficient estimates when they are presented in percentage form. The intercept terms are also scaled by $B_{t-1}$. The purpose of intercepts is to reflect the average change in budget which is independent of previous year's budget differences and other explanatory variables. For the term $\alpha_{0}$, it denotes the average change in estimated operating expenditure of agencies that overspend $\left(A_{t-1}>B_{t-1}\right)$ whilst $\alpha_{1}$ represents the difference in the intercept for agencies that underspend $\left(A_{t-1}<B_{t-1}\right)$. When $\alpha_{0}$ and $\alpha_{1}$ are summed up, it is the intercept term for agencies that underspend. The ratcheting coefficient is represented by $\lambda^{-}$in which it indicates the degree of budget adjustment done by administrator in response to budget variances. If the budget administrator shows more response towards overspending (current budget is adjusted more) than underspending, $\lambda^{+}$will be significantly positive and $\lambda^{-}$will be significantly negative.

The variable of change in emolument is remained in the research model to act as control variable to test the relative impact of budget ratcheting. This variable is included for the reason that the emolument cost constitutes a large fraction of an agency's total expenditures. It is expected that the coefficient of change in emolument to be significantly positive.

\subsection{Data Sampling Technique and Data Collection}

Sampling in research refers to collecting of information about a subset of individuals from within a population in order to infer information or to estimate an unknown characteristic about a population. Choosing appropriate sampling technique is fundamental to answer research questions and achieving research objective in the study. In order to fulfil the objectives of this study, the sampling technique that is being selected to conduct the study is total population sampling which is a type of purposive sampling technique. There are several reasons why this technique is chosen. First, the data needed for the study, namely federal government budget and actual expenditure covering the period from 2009 until 2014, are available and hardly incurred any expenses to obtain them. Second, the objective of this study is to examine ratcheting of 
budget in public sector, specifically federal government budget. Based on the data gathered, 14 agencies are allocated budget for charged expenditure whilst 35 agencies are allocated budget for supply expenditure. This suggests that the size of population in this study is relatively small and all these government agencies are of the same characteristic whereby their agency's programs and activities are supported by federal government budget. Therefore, total population sampling is deemed the most suitable sampling technique to be used to provide reliable observation in this study.

The study utilizes data from secondary source. Secondary data is data that has been collected and recorded by someone else before and for purpose other than the current project (Zikmund, Babin, Carr, \& Griffin, 2012). Secondary data is used in this study as it is considered the most suitable given the variables under consideration and the information needed are conveniently obtainable. The major source of data comes from the annual issue of the Federal Government Financial Statements published by the Accountant General's Department of Malaysia (here to include footnote as an address of website link). The annual report which is in dual language (Malay and English version) is downloadable from the department's website at www.anm.gov.my. This source is used because it contains quantitative data on both original budget and revised budget as well as data on actual expenditures which are presented by classification/component of operating expenditure for each department/agency in Malaysia. Reports at the website are available for five years, covering the period from year 2009 until 2013. In addition, information with regards to 2014 estimated federal expenditure is obtainable through the Treasury's website (at www.treasury.gov.my (it should be in the footnote)). Reports published both at the Accountant General's Department of Malaysia and the Treasury's website coincide with this study's proposed sample period. Reliable data is important in scientific research method so that results produced from the study are consistent. Since the budget and expenditure data are produced by official body, it is expected that the authenticity and reliability of the data will not be questionable.

\subsection{Data Analysis Method}

This study attempts to examine ratcheting of the federal government departments' budget in Malaysia covering from year 2010 until 2014. Since the data are in the form of cross-sectional (multi departments) and time series (several time periods), thus panel regression analysis is employed as statistical method in the study. Regression analysis is a statistical tool to determine whether two or more interval or ratio level variables are related. It enables researcher to find out how different values of one dependent variable may or may not be explained by the variation in the independent variable (McNabb, 2002, p. 218). There are several models and methods which are used to analyse the panel data is this study, namely Pooled Ordinary Least Squares, Random Effect Panel Regression Model, Fixed Effects Panel Regression Model, Breusch and Pagan LM Test and Hausman test. Diagnostic checks will also be carried out to check for collinearity or multicollinearity. Prior to the panel data analysis, Pearson Correlation Coefficient test is carried out to measure the strength of a linear association between two variables.

The data analysis and statistical software, Stata (version 11), is used to analyse all the data collection and interpret the result findings. This software is chosen because it has a particularly rich variety of panel analytic procedures and is very powerful in performing analysis on limited dependent variables which are compatible with the scope of this study. 


\section{(i) Descriptive Statistics Analysis}

Based on the Federal Government Financial Statements for year 2013 published by the Accountant General's Department of Malaysia, there are a total of 50 agencies/programs listed under operating expenditure. Operating expenditure consists of supply expenditure and charged expenditure such as emoluments, supplies and services, assets, grants and fixed charges, and other expenditure. There are 36 agencies/programs listed under supply expenditure and 14 agencies/programs under charged expenditure. Detailed list of agencies/programs according to the type of operating expenditure is attached in Appendix 1. Due to Cabinet reshuffle and restructuring of several agencies (ministry) during the study period, some data are incompleted which causes discontinuity in data. Therefore, only 30 agencies/ programs under supply expenditure together with all 14 agencies/programs under charged expenditure are included in the analysis.

Table 1 presents the breakdown of federal government budgeted operating expenditure for Malaysia federal government (30 agencies/programs under supply expenditure and 14 agencies/programs under charged expenditure) from 2010 until 2014. Both supply and charged expenditure have grown during the period. Total budgeted operating expenditure has increased from RM100,965,601,300.00 in year 2010 to RM161,536,941,000.00 in year 2014 (a $60 \%$ increase). Supply expenditure recorded a budget increase of $66.3 \%$ (from RM71,375,066,300 to RM118,693,650,000) whilst charged expenditure shows a lower budget growth of $44.8 \%$ (from RM29,590,535,000 to RM42,843,291,000) over the same period.

\section{Table 1 Breakdown of Federal Government Budgeted Operating Expenditure}

\begin{tabular}{ccccc}
\hline Year & No.n & $\begin{array}{c}\text { Supply } \\
\text { Expenditure } \\
\text { (RM) }\end{array}$ & $\begin{array}{c}\text { Charged Expenditure } \\
\text { (RM) }\end{array}$ & $\begin{array}{c}\text { Total Operating Expenditure } \\
\text { (RM) }\end{array}$ \\
\hline 2010 & 44 & $71,375,066,300$ & $29,590,535,000$ & $100,965,601,300$ \\
2011 & 44 & $86,043,755,600$ & $33,311,539,300$ & $119,355,294,900$ \\
2012 & 44 & $98,463,624,900$ & $35,288,886,200$ & $133,752,511,100$ \\
2013 & 44 & $110,296,531,000$ & $39,374,803,000$ & $149,671,334,000$ \\
2014 & 44 & $118,693,650,000$ & $42,843,291,000$ & $161,536,941,000$ \\
\hline
\end{tabular}

Table 2 summarizes the changes in operating expenditure budget of Malaysia federal government based on 220 total observations during the period from 2010 to 2014. It is observed that $71.36 \%$ of total observations have shown an increase in yearly budget while $23.64 \%$ of total observations recorded budget cut. Meanwhile, budget for $5 \%$ of total observations remain unchanged.

Table 2: Summary of Changes in Operating Expenditure Budget of Malaysia Federal Government (2010 - 2014)

\begin{tabular}{lcc} 
Changes in Budget & Number of Observation & Percentage \\
\hline Increased & 157 & 71.36 \\
Unchanged & 11 & 5.00 \\
Decreased & 52 & 23.64
\end{tabular}

The summary statistics of the variables included in the model of this study are presented in Table 3. On average, budgeted operating expenditures of federal government increase $13.56 \%$ 
annually over the period of year 2010 until 2014 with a standard deviation of 0.67 . The highest budget increase is $917 \%$ while the largest budget cut recorded is $82 \%$, possibly due to unforeseen major events that caused an agency/program's budget to change drastically. On average, actual operating expenditures do not approximate budgeted expenditures with a mean difference of $7.35 \%$. For $46.82 \%$ of the observations, budgeted operating expenditures exceed actual expenditures while for $53.18 \%$ of the observations, the actual expenditures exceed budgeted expenditures.

The budget for emolument shows an average change of $8.45 \%$ with a standard deviation of 0.18 . The minimum and maximum values of -0.4 and 1.62 indicate that the emolument budget for certain agency/program has undergone major reduction as much as $40 \%$ but there is also a sufficiently great increase in an agency's emolument budget of as high as $162 \%$.

\section{Table 3:. Summary Statistics for Model Variables}

\begin{tabular}{|c|c|c|c|c|c|}
\hline Variables & Observation & Mean & $\begin{array}{l}\text { Standard } \\
\text { Deviation }\end{array}$ & Minimum & Maximum \\
\hline $\mathrm{CB}$ & 220 & 0.1356 & 0.6700 & -0.8199 & 9.1704 \\
\hline DIUS & 220 & 0.0000 & 0.0000 & 0.0000 & 0.0000 \\
\hline $\mathrm{COS}$ & 220 & 0.0735 & 0.3449 & -0.8391 & 2.9309 \\
\hline DCUS & 220 & -0.0501 & 0.1061 & -0.08391 & 0.0000 \\
\hline $\mathrm{CE}$ & 220 & 0.0845 & 0.1771 & -0.3969 & 1.619 \\
\hline Percentage & with $\mathrm{U}=1$ & $46.82 \%$ & & & \\
\hline \multicolumn{6}{|c|}{ 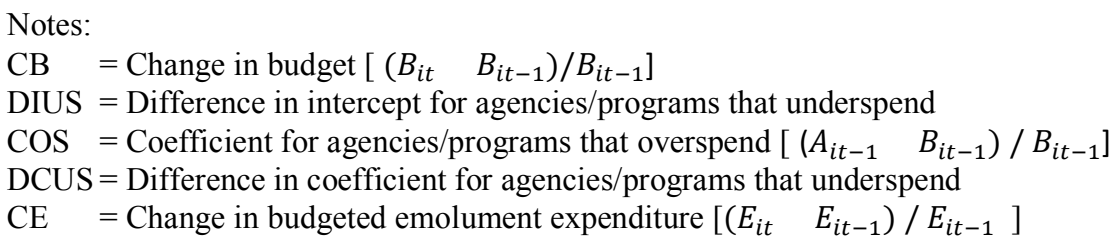 } \\
\hline
\end{tabular}

\section{(ii) Pearson Correlation Coefficient}

The positive values denote positive correlation which means that as one variable increases, the other variable has a tendency to also increase. Similarly, negative values denote negative correlation, that is, as one variable decreases, the other variable has a tendency to also decrease.

Table 4 shows that there exists either a moderate, weak or very weak relationship between the variables. All the variables demonstrate significant positive relationship with CB which is indicated by the positive values. In terms of strength of relationship between variables, only COS has shown moderate relationship $(r=0.3878)$ with CB at $1 \%$ significant level. As compared to COS, the relationship between DCUS and CE with CB is very weak in which the $r$ value is less than 0.19 at $1 \%$ and $5 \%(\mathrm{p}<0.05)$ significant level respectively. 
Table 4. Pearson Correlation Coefficient of All Variables

\begin{tabular}{lccccc}
\hline Variable & CB & DIUS & COS & DCUS & CE \\
\hline CB & 1.0000 & & & & \\
DIUS &. &. & & & \\
& $\cdot$ & & & & \\
COS & $0.3878^{* * *}$ &. & 1.0000 & & \\
& 0.0000 & & & & \\
DCUS & $0.1454^{* *}$ &. & $0.4775^{* * *}$ & 1.0000 & \\
& 0.0311 &. & 0.0000 & & \\
CE & $0.1819^{* *}$ &. & 0.0451 & $0.1377^{* *}$ & 1.0000 \\
& 0.0068 &. & 0.5061 & 0.0413 & \\
\hline
\end{tabular}

Notes: $\mathrm{CB} \quad=$ Change in budget $\left[\left(\begin{array}{ll}B_{i t} & B_{i t-1}\end{array}\right) / B_{i t-1}\right]$; DIUS = Difference in intercept for agencies/programs that underspend ; $\operatorname{COS}=$ Coefficient for agencies/programs that overspend $\left[\left(\begin{array}{ll}A_{i t-1} & B_{i t-1}\end{array}\right) / B_{i t-1}\right]$; DCUS = Difference in coefficient for agencies/programs that underspend; $\mathrm{CE}=$ Change in budgeted emolument expenditure $\left[\left(E_{i t} \quad E_{i t-1}\right) / E_{i t-1}\right]$; $* *$ and $* * *$ denotes significance at $5 \%$ and $1 \%$ levels respectively. DIUS is omitted because of collinearity

(iii) Pooled Ordinary Least Squares

Pooled Ordinary Least Squares (OLS) is a method used to estimate a common constant for all cross sections. This type of regression is the easiest to run and it is a simple and quick benchmark to which more sophisticated regressions can be compared. Therefore, it is also often used as a rough and ready means of analysing the data.

Table 5 shows that the R-squared of the model in this study is 18.21 , indicating that the independent and control variables only explain $18.21 \%$ of the dependent variable, that is, change in budget. In other words, around $82 \%$ of the independent variable is explained by other variables, which implies that there are several important factors not captured by the model. The results from this analysis also show that $\mathrm{COS}$ and $\mathrm{CE}$ have positive impact on $\mathrm{CB}$ which is significant at $1 \%$ level $(\mathrm{p}<0.01)$. However, DCUS is not significant at $5 \%$ level ( $\mathrm{p}$-value $=$ $0.2730>0.05)$.

Table 5. Pooled Ordinary Least Squares Analysis

\begin{tabular}{lcccc} 
Variable & Coefficient & Standard error & T value & P-value/sig. \\
\hline COS & 0.8103 & 0.1361 & 5.9500 & $0.0000^{* * *}$ \\
DCUS & -0.4907 & 0.4461 & -1.1000 & 0.2730 \\
CE & 0.6572 & 0.2350 & 2.8000 & $0.0060^{* * *}$ \\
Constant & -0.0041 & 0.0550 & -0.0700 & 0.9410 \\
F value & & & & 16.0300 \\
F significance & & & 0.0000 \\
R-squared & & & & 0.1821 \\
Adjusted R-squared & & & 0.1707 \\
\hline
\end{tabular}

Notes: $* * *$ denotes significance at $1 \%$ level ( $\mathrm{p}$-value $<0.01)$.

1. DIUS is omitted because of collinearity. 


\section{(iv) Random Effects Panel Regression Model}

Random effects model assumes that variation across entities is random and uncorrelated with the predictor or independent variables. This random effects model can be used when the differences across entities are believed to have some influence on the dependent variable. One of the advantages of using random effects model is that time-invariant variables can be included to play a role as explanatory variables. Nevertheless, this model has its disadvantage whereby some variables may not be available which causes omitted variable bias in the model.

Based on the overall R-squared value derived from the analysis which is illustrated in Table $6,18.21 \%$ of the variance of dependent variable, that is change in budget, can be explained by the independent variables included in this study, while the remaining $81.79 \%$ is explained by other variables that are not included in the model. The R-squared within value of 0.1955 indicates that one agency/program variable explains $19.55 \%$ of change in budget whereas the R-squared between value of 0.1557 indicates that variables among the agencies/programs are able to explain $15.57 \%$ of the change in budget. The results of the analysis show that COS and $\mathrm{CE}$ are significantly and positively related to change in budget at $1 \%$ level $(\mathrm{p}<0.01)$. However, DCUS is not significant at $5 \%$ level $(p$-value $=0.2710>0.05)$.

Table 6. Random Effects Panel Regression Model Analysis

\begin{tabular}{|c|c|c|c|c|}
\hline Variable & Coefficient & Standard error & $\mathrm{Z}$ value & P-value/sig. \\
\hline COS & $0.8103 * * *$ & 0.1361 & 5.9500 & 0.0000 \\
\hline DCUS & -0.4907 & 0.4461 & -1.1000 & 0.2710 \\
\hline $\mathrm{CE}$ & $0.6572 * * *$ & 0.2350 & 2.8000 & 0.0050 \\
\hline Constant & -0.0041 & 0.0550 & -0.0700 & 0.9410 \\
\hline \multicolumn{4}{|l|}{ F value } & 48.0800 \\
\hline \multicolumn{2}{|c|}{ F significance } & & & 0.0000 \\
\hline \multicolumn{5}{|c|}{ R-squared: } \\
\hline & Within & & & 0.1955 \\
\hline & Between & & & 0.1557 \\
\hline & Overall & & & 0.1821 \\
\hline
\end{tabular}

\section{(v) Fixed Effects Panel Regression Model}

Fixed effects model assumes that something within the individual may cause the predictor or outcome variables to become bias or be impacted and therefore there is a need to control for that. Fixed effects model removes the effect of those time-invariant characteristics so that the net effect of the predictors or outcome variable can be examined. As the model assumes that time-invariant characteristics are unique to the individual, hence the entity's error term and the constant should not be correlated with the others.

Table 7 shows that $17.67 \%$ of variance of change in budget, represented by the overall Rsquared value of 0.1767 , is explained by the variables in the model whilst $82.33 \%$ is described by other variables that are not included in the model. Results from the analysis show that only 
COS is significantly and positively associated with change in budget at $1 \%$ significance level whereas both DCUS and CE are not significant at 5\% level $(p>0.05)$.

\section{(vi) Breusch and Pagan LM Test}

The Breusch and Pagan LM test is conducted to decide between a simple ordinary least squares regression and random effects regression in terms of their appropriateness or goodnessof-fit with regards to the model under study. The null hypothesis in the LM test is that variances across entities are zero, meaning there is no significant difference across units (no panel effect). Meanwhile, the alternate hypothesis is that variances across entities are not equal to zero. This is shown as below:

H0: Pooled Ordinary Least Squares Model; H1: Random Effects Panel Regression Model

\section{Table 7. Fixed Effects Panel Regression Model Analysis}

\begin{tabular}{lcccc}
\hline Variable & Coefficient & Standard error & T value & P-value/sig. \\
\hline COS & 0.9497 & 0.1701 & 5.5800 & 0.0000 \\
DCUS & -0.2044 & 0.6109 & -0.3300 & 0.7380 \\
CE & 0.4989 & 0.2618 & 1.9100 & 0.0580 \\
Constant & 0.0134 & 0.0635 & 0.2100 & 0.8330 \\
F value & & & & 0.8500 \\
F significance & & & 0.7369 \\
R-squared: & & & & 0.2009 \\
& Within & & & 0.1276 \\
& Between & & & 0.1767 \\
& Overall & & & \\
\end{tabular}

Notes: $* * *$ denotes significance at $1 \%$ level (p-value $<0.01$ ); DIUS is omitted because of collinearity.

If the p-value from the test is less than 0.05, null hypothesis is rejected and Random Effects Regression Model (alternate hypothesis) is appropriate for the study. However, if p-value is greater than 0.05, null hypothesis should not be rejected and therefore Pooled Ordinary Least Squares Model is more suitable for the study. Table 8 shows that p-value from the Breusch and Pagan LM test is 1.0000 which is greater than 0.05 , thus null hypothesis (H0) should not be rejected. For that matter, Pooled Ordinary Least Squares Model is chosen as the appropriate model for the study.

Table 8. Breusch and Pagan LM Test Result

\begin{tabular}{|c|c|c|c|}
\hline Variable & \multicolumn{2}{|c|}{ Var } & $\mathrm{sd}=\operatorname{sqrt}(\operatorname{Var})$ \\
\hline CB & \multicolumn{2}{|c|}{0.4489} & 0.6700 \\
\hline e & \multicolumn{2}{|c|}{0.3841} & 0.6198 \\
\hline \multirow[t]{4}{*}{ u } & \multicolumn{2}{|c|}{0.0000} & 0.0000 \\
\hline & Test: $\operatorname{Var}(\mathrm{u})$ & $=0$ & \\
\hline & $\operatorname{chi} 2(1)$ & $=0.0000$ & \\
\hline & Prob $>$ chi 2 & $=1.0000$ & \\
\hline
\end{tabular}

H0 = Pooled OLS; H1 = Random Effects Panel Regression Model 
Hausman test is proposed with the aim of choosing between Fixed Effects and Random Effects Panel Regression Model. The Hausman test is performed to check a more efficient model against a less efficient but consistent model in order to make sure that the more efficient model also provides consistent results. There are two hypotheses in this test: H0: Random Effects Panel Regression Model; H1: Fixed Effects Panel Regression Model. If the p-value is less than 0.05 (p $<0.05)$, then H0 is rejected and thus Fixed Effects Panel Regression Model is chosen as the more appropriate model. However, if the p-value is greater than 0.05, then H0 should not be rejected and therefore Random Effects Panel Regression Model is more suitable for the study. Based on the Pooled Ordinary Least Squares and Random Effects Panel Regression Model tests that have been conducted, both display very similar results wherein the coefficient estimates of the variables are the same with slight difference in the p-value. In addition, the Breusch and Pagan LM test results shows that the p-value is 1.0000. Therefore, it is deemed unnecessary to perform Hausman test in this study.

\section{(vii) Diagnostic Checks}

Diagnostic checks are performed on data to detect the problem of multicollinearity. Multicollinearity means that two or more explanatory variables in a multiple regression model are highly correlated. When the degree of multicollinearity increases, the regression model estimates of the coefficients become unstable and imprecise. This means it becomes difficult to assign the change in the dependent variable precisely to one or the other of the explanatory variables. One of the approaches to identify multicollinearity is through the use of variance inflation factor (VIF) whereby it measures how much the variances of the estimated regression coefficients are inflated as compared to when the explanatory variables are not linearly related. Values of VIF that exceed 10 are often regarded as indicating multicollinearity. The results of multicollinearity test in which the mean of VIF is 1.21 . As the value is less than 10 , it suggests that there is no multicollinearity problem in the regression model of this study.

\section{DISCUSSION ON FINDINGS}

The objective of this study is to examine the relationship between changes in current budget and expenditure variances in Malaysia federal government organisations. The study focuses on operating expenditure budget (supply expenditure and charged expenditure) of government agencies/programs from year 2010 to 2014 involving 220 observations (30 agencies/programs under supply expenditure and 14 agencies/programs under charged expenditure).It is observed that nearly three-quarters of total observations recorded yearly increase in operating expenditure budget throughout the study period from 2010 until 2014. This budget increase trend for majority of the Malaysia federal government agencies/programs is consistent with Niskanen's (1971) budget-maximizing model whereby he advocates that bureaucrats tend to pursue budgetmaximizing strategy for self-interest reason as well as study by Anessi-Pessina, Sicilia and Steccolini (2012) which evidenced that upward revisions to the budget are more frequent than downward adjustments.

The occurence of overspending among federal government agencies/programs is also found to be higher in comparison to underspending. This implies that there might be inefficiency in government budget planning, possibly the result of qualitative approach (experience and game-playing) undertaken by government officials in estimating budget for their agency/program (Doh, 1991). Hence, it is crucial to analyse government budget so that budgetary control can be refined to improve capacity to budget and ensure proper usage of public money. 
Pooled Ordinary Least Squares is appropriate over the Random Effects Panel Regression Model. Thus, the results from Pooled Ordinary Least Squares analysis will be used to discuss the findings for hypotheses and make conclusions for the study. Table 9 presents results for budgeted operating expenditures. This study first hypothesized that there is significant positive relationship between Malaysia federal government agency/program's prior year operating expenditure overspending and changes in current budget (H1). Result from the analysis supports this hypothesis $\left(\lambda^{+}=0.8103, \mathrm{p}=0.0000<0.01\right)$. The coefficient estimate for overspending $\left(\lambda^{+}\right)$ is 0.8103 and significant, suggesting that when the prior year's actual operating expenditure exceed budgeted expenditures, approximately $81.03 \%$ of that variance is reflected in the budget increase for the current year.

The second hypothesis for the study, $\mathrm{H} 2$, is that there is significant negative relationship between Malaysia federal government agency/program's prior year operating expenditure underspending and changes in current budget. Result from the analysis shows that there is negative relationship between these two variables but not significant $\left(\lambda^{-}=-0.4908, p=0.273>\right.$ 0.05). This finding is found to be in contrast with Lee and Plummer (2007) who reported $\lambda^{-}$will be significantly negative.

According to Lee and Plummer (2007), if administrators adjust budgets in response to expenditure variances but respond more to overspending than underspending, $\lambda^{+}$will be significantly positive and $\lambda^{-}$will be significantly negative. As the findings from this study only support H1 (There is significant positive relationship between Malaysia federal government agency/program's prior year operating expenditure overspending and changes in current budget) but not H2 (There is significant negative relationship between Malaysia federal government agency/program's prior year operating expenditure underspending and changes in current budget),

As for the control variable, result shows that there is significant positive relationship between CE and CB (explain full word not in abbreviations) (coefficient $=0.6572, \mathrm{p}=0.006<$ $0.05)$. This implies that current budget of the agency/program will experience changes when there is change in budgeted emolument expenditure. This result is consistent with study by Lee and Plummer (2007).

Table 9:. Tests of Budget Ratcheting Using Operating Expenditure

\begin{tabular}{lcccc}
\hline \multicolumn{1}{c}{ Variable } & Coefficient & $\begin{array}{c}\text { Predicted } \\
\text { Sign }\end{array}$ & $\begin{array}{c}\text { Coefficient } \\
\text { Estimate }\end{array}$ & t-statistic \\
\hline $\begin{array}{l}\text { Intercept (scaled) for } \mathrm{U}=0 \\
\text { agency/program }\end{array}$ & $\alpha_{0}$ & $?$ & -0.0041 & -0.07 \\
$\begin{array}{l}\text { Intercept (scaled) for } \mathrm{U}=1 \\
\text { agency/program }\end{array}$ & $\alpha_{0}+\alpha_{1}$ & $?$ & Nil & Nil \\
$A_{i t-1} \quad B_{i t-1}$ & $\lambda^{+}$ & + & 0.8103 & $5.95^{* * *}$ \\
$U \quad\left(A_{i t-1} \quad B_{i t-1}\right)$ & $\lambda^{-}$ & & & \\
$\left(E_{i t} \quad E_{i t-1}\right)$ & $\alpha_{2}$ & + & 0.6572 & $2.80^{* * *}$ \\
\hline
\end{tabular}

Notes: $* * *$ denotes significance at $1 \%$ level ( $\mathrm{p}$-value $<0.01$ ).

1. Intercept (scaled) for $U=1$ agency/program is nil because DIUS is omitted due to collinearity. 


\section{CONCLUSION AND CONTRIBUTION}

The study found that there is significant positive relationship between changes in budget and overspending by agency/program. However there is no prior research to support the second hypothesis, which is, there is significant negative relationship between changes in budget and underspending by agency/program. These findings indicate that budget administrators of federal government of Malaysia adjust their agency/program's current budget upwardly in response to overspending in prior year. However, if there is downward revision of current budget by the agency/program, such revision does not necessarily derives from the response towards prior year's underspending. Because of that, the presence of budget ratcheting in public sector, specifically Malaysia federal government, is not able to be determined. Another study can be carried out in future to identify and addresses more factors that might exist in public budget management so as to improve government accountability as well as equitable distribution of wealth in Malaysia.

During the process of conducting this study, two main limitations were encountered. First, the elements of inflation and purchasing power are ignored in the study. This implies that the real growth in government expenditures cannot be gauged and therefore the results may not reflect the actual scenario of the public budget in Malaysia. It is suggested that future study to take into account the inflation and purchasing power factor when conducting the analysis so that the real amount or value of the public budget can be captured and analysed to better represent the actual budget changes in Malaysia's federal government.

Second, there exists the problem of discontinuity of data in the study. This is mainly due to the Cabinet reshuffle and restructuring of several ministries during the study period which leads to incomplete data for several agencies/programs. Therefore, it is recommended that future study to approach the respective official body to obtain detailed data of budget and expenditure for every agency/program. This will allow the treatment of data to be carried out and subsequently enables a comprehensive analysis done on the topic of budget ratcheting. Perhaps future study can also look into the analysis of comparison among sub-component of operating budget that is between supply expenditure and charged expenditure, or comparison between agency/program so that specific issues can be identified. When these issues are clearly defined, the solutions proposed will be more focused and result-oriented, and thus contribute to the efficiency and effectiveness of public budget management in Malaysia.

\section{REFERENCES}

Allen, R., \& Tommasi, D. (Eds.) (2001). Managing public expenditure: A reference book for transition countries. Paris, France: OECD.

Anderson, M., Banker, R., \& Janakiraman, S. (2003). Are Selling, General, and Administrative Costs "Sticky"? Journal Of Accounting Research, 41(1), 47-63.

Anessi-Pessina, E., Sicilia, M., \& Steccolini, I. (2012). Budgeting and Rebudgeting in Local Governments: Siamese Twins? Public Administration Review, 72(6), 875-884.

Aranda, C., Arellano, J., \& Davila, A. (2014). Ratcheting and the role of relative target setting. Accounting Review, 89(4), 1197-1226. doi:10.2308/accr-50733.

Balakrishnan, R., \& Gruca, T. S. (2008). Cost Stickiness and Core Competency: A Note. Contemporary Accounting Research, 25(4), 993-1006.

Bellante, D., \& Porter, P. (1998). Public and Private Employment Over the Business Cycle: A Ratchet Theory of Government Growth. Journal Of Labor Research, 19(4), 613-628. 
Bevan, G., \& Hood, C. (2006). What's measured is what matters: Targets and gaming in the English public health care system. Public Administration, 84(3), 517-538. doi:10.1111/j.14679299.2006.00600.x.

Bovens, M. (2007). Analysing and assessing accountability: A conceptual framework. European Law Journal, 13(4), 447. doi:10.1111/j.1468-0386.2007.00378.x.

Broyles, R. W., Khaliq, A. A., \& Mattachione, S. E. (2009). A variance analysis of the contribution margin: An approach to improving financial performance and reducing fiscal risk. Research In Healthcare Financial Management, 12(1), 77-92.

Casas-Pardo, J., \& Puchades-Navarro, M. (2001). A critical comment on Niskanen's model. Public Choice, 107(1/2), 147-167.

Cassar, G., \& Gibson, B. (2008). Budgets, internal reports, and manager forecast accuracy. Contemporary Accounting Research, 25(3), 707-738. doi:10.1506/car.25.3.3.

Conybeare, J. A. (1984). Bureaucracy, monopoly, and competition: A critical analysis of the budgetmaximizing model of bureaucracy. American Journal Of Political Science, 28(3), 479.

Devarajan, S., Swaroop, V., \& Zou, H. F. (1996). The composition of public expenditure and economic growth. Journal of monetary economics, 37(2), 313-344.

Doh, J. C. (1991). Expenditure forecasting in selected operating departments in three states of Malaysia. Public Budgeting \& Finance, 11(2), 108-119

Ekholm, B., \& Wallin, J. (2000). Is the annual budget really dead?. European Accounting Review, 9(4), 519. doi:10.1080/09638180020024007

Ettredge, M. L., Bedard, J. C., \& Johnstone, K. M. (2008). Empirical tests of audit budget dynamics. Behavioral Research in Accounting, 20(2), 1-18

Hercowitz, Z., \& Strawczynski, M. (2004). Cyclical ratcheting in government spending: Evidence from the OECD. Review Of Economics \& Statistics, 86(1), 353-361.

Higgs, R. (1987). Crisis and Leviathan: Critical episodes in the growth of American government. Oxford: Oxford University Press.

Holthausen, R., Larcker, D., \& Sloan, R. (1995). Annual bonus schemes and the manipulation of earnings. Journal Of Accounting And Economics, 19(1), 29-74. doi:10.1016/0165-4101(94)00376G.

Indjejikian, R. J., Matějka, M., \& Schloetzer, J. D. (2014). Target ratcheting and incentives: Theory, evidence, and new opportunities. Accounting Review, 89(4), 1259-1267. doi:10.2308/accr-50745.

Indjejikian, R., \& Nanda, D. (2003). Reply to: Dynamic incentives and responsibility accounting: A comment. Journal Of Accounting And Economics, 35(3), 437-441. doi:10.1016/S01654101(03)00041-7.

Jensen, M. C. (2001). Corporate budgeting is broken - Let's fix it. Harvard Business Review, 79(10), 94101.

Kaplan, R. S. (2010). Conceptual foundations of the balanced scorecard (Working Paper No. 10-074). Retrieved from Harvard Business School website: http://www.hbs.edu/faculty/Publication\%20Files/10-074.pdf.

Kidwell, L. A. (1999). Compliance reporting decisions in municipal audits: The impact of budget variance and employment sector. Journal of Public Budgeting, Accounting and Financial Management, 11(3), 326-354.

Kloot, L., \& Martin, J. (2001). Local government accountability: Explaining differences. Accounting, Accountability \& Performance, 7(1), 51-72. 
Lee, T. M., \& Plummer, E. (2007). Budget adjustments in response to spending variances: Evidence of ratcheting of local government expenditures. Journal of Management accounting research, 19(1), 137-167.

Leone, A. J., \& Rock, S. (2002). Empirical tests of budget ratcheting and its effect on managers' discretionary accrual choices. Journal of Accounting and Economics, 33(1), 43-67.

Marcino, G. R. (2000). Obliterate traditional budgeting. Financial Executive, 16(6), 29-31.

Marginson, D., Ogden, S., \& Frow, N. (2006). Budgeting and innovation: Complements or contradictions?. Retrieved May 13, 2015, from CIMA website: http://prelivewww.cimaglobal.com/Documents/Thought_leadership_docs/MigratedDocsMarch201 0/Resouces\%20(pdfs)/Research\%20full\%20reports/Budgeting\%20and\%20innovation\%20comple ments\%20or\%20contradictions.pdf.

Marino, A. M., \& Matsusaka, J. G. (2005). Decision processes, agency problems, and information: An economic analysis of capital budgeting procedures. The Review of Financial Studies, 18(1), 301325. doi:10.1093/rfs/hhh005.

McGuire, T. G. (1981). Budget-maximizing governmental agencies: An empirical test. Public Choice, 36(2), 313-322.

McNabb, D. E. (2002). Research methods in public administration and nonprofit management: Quantitative and qualitative approaches. Armonk, New York : M.E. Sharpe.

Migué, J., \& Bélanger, G. (1974). Toward a general theory of managerial discretion. Public Choice, 1727-47.

Miller, D. C. (1991). Handbook of research design and social measurement (5 $5^{\text {th }}$ ed.). Newbury Park, California: Sage Publications.

Nasaruddin Arshad, \& Zulkifly Mustapha. (1988). Malaysian government expenditure: An analysis of pattern and probable distribution impact. Analisis, 3(1\&2), 23-36.

Otley, D., \& Fakiolas, A. (2000). Reliance on accounting performance measures: dead end or new beginning?. Accounting, Organizations And Society, 25497-510. doi:10.1016/S03613682(98)00007-5.

Penner, S. J. (2004). Controlling budget variance. Nursing Homes: Long Term Care Management, 53(10), 86-88.

Perrin, B. (2015). Bringing accountability up to date with the realities of public sector management in the 21st century. Canadian Public Administration, 58(1), 183-203. doi:10.1111/capa.12107.

Phadoongsitthi, M. (2003). The role of managerial accounting in emerging economies: An empirical study of Thailand. (Doctoral dissertation, University of Maryland, College Park, 2003). Retrieved May 13, 2015, from Thammasat University website: http://dspace.library.tu.ac.th/handle/3517/2060.

Pollack, R. N. (2014). Financial Management for Firms: Accounting, Billing, and Budgeting. Contract, 55(5), 34.

Ratchet. (2015). In Oxford English dictionary online. Retrieved May 12, 2015, from http://www.oxforddictionaries.com/definition/english/ratchet.

Robbins, W., \& Taylor, G. (2013). Management accounting systems adoption: Evidence and performance implications for the nonprofit healthcare sector. International Research Journal of Applied Finance, 4(8), 939-1079.

Robinson, M. (2002). Financial control in Australian government budgeting. Public Budgeting \& Finance, 22(1), 80-93. 
Roland, G. (2013). Private and public ownership in economic theory. In G. Roland (Ed.), Privatization: Successes and failures (pp. 9-31). New York: Columbia University Press.

Roland, G., \& Szafarz, A. (1990). The ratchet effect and the planner's expectations. European Economic Review, 34(5), 1079-1098. doi:10.1016/0014-2921(90)90024-S.

Schmidt, J. A. (1992). Is it time to replace traditional budgeting?. Journal Of Accountancy, 174(4), 103107

Sigelman, L. (1986). The bureaucrat as budget maximizer: An assumption examined. Public Budgeting \& Finance, 6(1), 50-59

Smyth, R. (2004). Exploring the usefulness of a conceptual framework as a research tool: A researcher's reflections. Issues In Educational Research, 14(2), 167-180. http://www.iier.org.au/iier14/smyth.html

Stonkute, E., \& Žukaskas, P. (2003). Management control system's design: Theoretical concepts. Management Of Organizations: Systematic Research, (25), 273-286

Tirole, J. (1994). The Internal Organization of Government. Oxford Economic Papers, 46(1), 1-29

Trebby, J. P., \& Daniker, R. P. V. (1986). Relationship of budgeting and accounting: Implication for public policy. Journal of Applied Business Research, 2(4), 23-32

Van der Hoek, M. P. (2005). From cash to accrual budgeting and accounting in the public sector: The Dutch experience. Public Budgeting \& Finance, 25(1), 32-45

Vasarhelyi, M. A., \& Mock, T. J. (1977). An information processing analysis of budget variance information. (Unpublished papers). University of California, United States. Retrieved May 14, 2015, from http://www.business.rutgers.edu/sites/default/files/user_files/cv-miklos-vasarhelyi.pdf

Webb, R. A. (2002). The impact of reputation and variance investigations on the creation of budget slack. Accounting, Organizations And Society, 27361-378. doi:10.1016/S0361-3682(01)00034-4

Weitzman, M. L. (1980). The "ratchet principle" and performance incentives. Bell Journal of Economics, 11(1), 302-208

Wooldridge, S., Garvin, M., \& Miller, J. (2001). Effects of accounting and budgeting on capital allocation for infrastructure projects. Journal Of Management In Engineering, 17(2), 86-94. doi:10.1061/(ASCE)0742-597X(2001)17:2(86)

Yap, A. K. H., Lee, T. H., Jamaliah Said, \& Yap, S. T. (2013). Adoption, benefits and challenges of strategic, management accounting practices: Evidence from emerging market. Asia Pacific Management Accounting Journal, 8(2), 27-45

Yeoh, M., \& Stansel, D. (2013). Is public expenditure productive? Evidence from the manufacturing sector in U.S. cities, 1880-1920. CATO Journal, 33(1), 1-28

Zikmund, W. G., Babin, B. J., Carr, J. C., \& Griffin, M. (2012). Business Research Methods (9th ed.). Mason, $\mathrm{OH}$ : South-Western Cengage Learning

Correspondig Author: Daw Tin Hla can be contacted at thdaw@unimas.my 